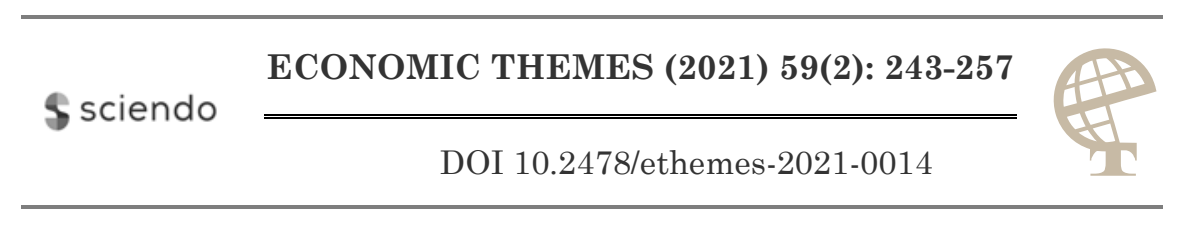

\title{
MODELLING DEVELOPMENT OF VOLUNTARY PENSION FUND USING MATHEMATICAL MODEL OF APPROXIMATION WITH LAGRANGE INTERPOLATION POLYNOMIALS
}

\author{
Ivan Radojković \\ "Dunav", voluntary pension fund management company, Serbia \\ \ivan.radojkovic@dunavpenzije.com \\ Branislav Ranđelović \\ University of Niš, the Faculty of Electronic Engineering, Serbia \\ $\bowtie$ branislav.randjelovic@elfak.ni.ac.rs
}

\author{
Ivana Ilić \\ University of Niš, the Faculty of Medicine, Serbia \\ $\triangle$ ivanailicc3@gmail.com
}

\begin{abstract}
UDC
364.35

Abstract: Corporate social responsibility (CSR), as a concept that tackles economic, The introduction of private pension funds is the essence of the reform of the pension system in Serbia. Private pension funds in Serbia are based on voluntary benefits. Thus, the functioning of the pension system takes place in three interconnected processes: payments to a voluntary pension fund, investment of free funds, and ultimately programmed

Review paper payments - pensions. The stability in the voluntary pension funds and the predictability of payments allow the quality of investment portfolio to be formed and achieve a long-term yield of investment. In this paper, we implement a well-known approximation method of Lagrange polynomial interpolation. We use it in order to find appropriate mathematical model for prediction of the number of fund members and the average salary in Serbia. This calculation is based on data (average salaries and fund member) from the last five years, i.e. from the period 2015-2019. We calculated the exact mathematical formula, then we compared the results and predictions obtained with that formula and with the formula from one of our previous works. In keeping with that, the appropriate conclusions were given..
\end{abstract}

Received:

26.01.2021

Accepted:

28.04.2021

Keywords: pension system, voluntary pension funds, mathematical model, Lagrange interpolation..

JEL classification: C38, G11, G23, J32

This work is supported by Ministry of Education, Science and Technological development of the Republic of Serbia, under Grants TR-32012 and III-43007. 


\section{Introduction}

A large number of existing pension insurance systems in the world have three pillars. In Serbia, the introduction of the second pillar is not finished, so we have the first and the third pillar. Voluntary pension funds in Serbia were introduced in 2005.

There are seven voluntary pension funds in Serbia, managed by four management companies. Fund members can start withdrawing funds at the age of 53 or 58, depending on the moment they joined the Fund (www.dunavpenzije.com). The problem of saving the population has several sides, and it is certain that some of the causes can be recognized in bad experiences from the past, for example, see (Đekić M, et al. 2019).

The "pay as you go" financing system can work well if the national economy is on the rise and when the number of employees is significantly higher than the number of retirees. This is not the situation in Serbia today, but it is similar in many countries around the Europe and the world. If there is no economic selfsustainability of the public pension fund, financed according to the "pay as you go" principle, the state inevitably intervenes as a financier using general budget funds, and if they are insufficient, it uses special taxes on tobacco, alcohol, gas, luxury goods, etc. (Kočović J, et al, 2010, p.493).

The period of membership in the pension fund is divided into two phases:

- the accumulation phase (the period during which the funds are paid) and

- the withdrawal phase (the period during which the member withdraws the accumulated funds) (www.nbs.rs).

At the end of the fourth quarter of 2019, 201,587 users (www.nbs.rs) in Serbia were in the accumulation phase. It will be interesting to see at the end of 2020 how COVID-19 will affect the number of users and FONDEX, i.e. the real power of voluntary pension funds will be shown.

The stability of inflows into voluntary pension funds and the predictability of payments enable the formation of a quality investment portfolio and the realization of a long-term return on investment (Radojković I., Gajić B. 2017, p.34). The strategic goal in this area is to introduce a healthy multi-pillar pension system (Radojković I, 2012, p.41).

The data in following the table indicate solid returns of funds, which indicates that the funds place the collected funds well. 
Table 1. Number of members, assets and rates of return for voluntary pension funds operating in Serbia (www.raiffeisenfuture.rs)

\begin{tabular}{lccc}
\hline Fund & Members & $\begin{array}{c}\text { Assets (in millions } \\
\text { of RSD) }\end{array}$ & Yield (2019) \\
\hline 1 Generali Basic & 46535 & $13.075,8$ & $9,14 \%$ \\
\hline 2 Generali Index & 4966 & $1.095,6$ & $8,34 \%$ \\
\hline 3 Raiffaisen Future & 35064 & $5.459,9$ & $4,87 \%$ \\
\hline 4 Raiffaisen Euro Future & 4464 & 225 & $2,91 \%$ \\
\hline 5 DDOR GarantEkvilibrio & 53517 & $6.050,3$ & $5,63 \%$ \\
\hline 6 DDOR GarantŠtednja & 19287 & $1.328,4$ & $7,85 \%$ \\
\hline 7 DUNAV & 87195 & $18.010,5$ & $6,80 \%$ \\
\hline
\end{tabular}

Source: Statistical Anex of NBS for December 2019.

Yield rates of voluntary pension funds are also favorable if the exchange rate movements during the last year are taken into account. On January $3^{\text {rd }}, 2019,1$ euro was equivalent to 118.3439 dinars (www.kamatica.rs) and on December $31^{\text {st }}, 2019$, 1 euro was equivalent to 117.5928 (www.kamatica.com). In percentage, the fall of the euro is $0.64 \%$, while the annual inflation in 2019 was $1.9 \%$ (www.cekos.rs).

\section{Graph 1. Share of each pension fund in overall number of members in Serbia} (www.raiffeisenfuture.rs)

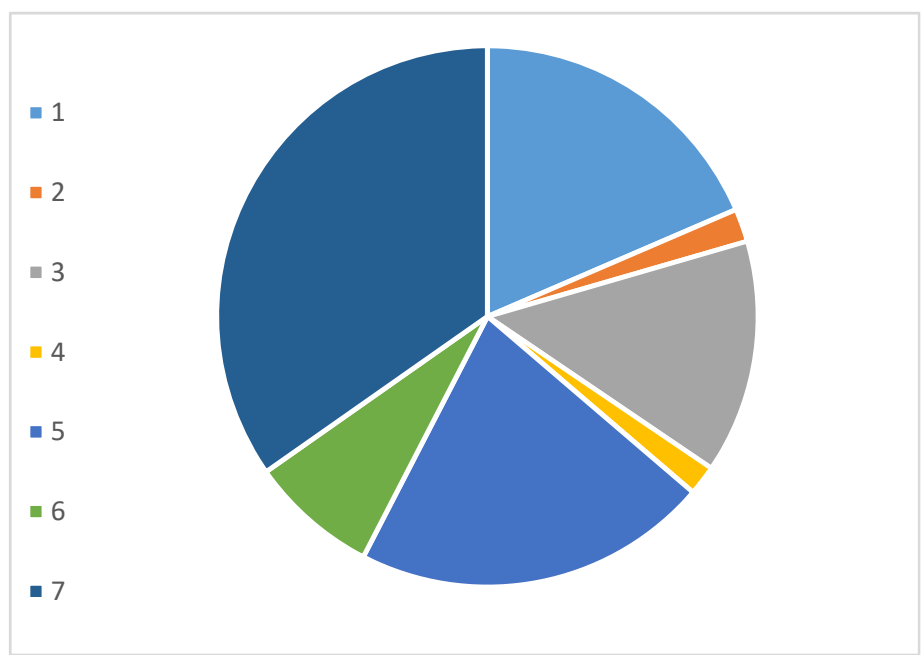

Source: Statistical Annex of NBS for December 2019. 
Table 2. Key indicators of voluntary pension funds in Serbia development

\begin{tabular}{cccccc}
\hline Indicators & $\begin{array}{c}\text { Companies for } \\
\text { managing } \\
\text { voluntary pension } \\
\text { funds }\end{array}$ & $\begin{array}{c}\text { Voluntary } \\
\text { pension } \\
\text { funds }\end{array}$ & Members & Contracts & $\begin{array}{c}\text { Net estate of } \\
\text { funds in } \\
\text { millions RSD }\end{array}$ \\
\hline 2010 & 6 & 8 & 166780 & 220451 & $9.862,7$ \\
\hline 2011 & 6 & 9 & 174868 & 234405 & 12.452 .3 \\
\hline 2012 & 5 & 9 & 179823 & 240369 & $16.011,3$ \\
\hline 2013 & 4 & 6 & 183508 & 244462 & $19.007,7$ \\
\hline 2014 & 4 & 6 & 187997 & 252072 & $23.565,3$ \\
\hline 2015 & 4 & 7 & 190492 & 258680 & $28.874,8$ \\
\hline 2016 & 4 & 7 & 183553 & 250460 & $32.790,1$ \\
\hline 2017 & 4 & 7 & 185445 & 253900 & $36.200,0$ \\
\hline 2018 & 4 & 7 & 192295 & 261726 & $40.185,0$ \\
\hline 2019 & 4 & 7 & 201587 & 275833 & $45.245,5$ \\
\hline
\end{tabular}

Source: www.nbs.rs

Based on the information in Table 2, positive trends can be observed in the growth of the Fund's net assets, as well as in the number of beneficiaries. The influence of various factors in society on the development of pension funds, as well as the possibility of predicting development in this domain, are the subject of a number of papers from different countries and parts of the world, on which we based our research in this paper (Benediktsson H.C., et al 2001; Blake D, 2004; Chlon S, 2002; Dellvaand W.L., et al 1998; Ottenand R, et al 2002; Shamsuddin, A.F.M. 2001; Kabašinkskas A.,et al 2017; Marti C., et al 2009; Bikker J, et al 2011; Cheng Ch., et al 2016; Gerke W, et al 2008).

\section{Lagrange polynomial interpolation method}

Let the function $f$ be given with its values

$$
f_{k} \equiv f\left(x_{k}\right)
$$

at some fixed points $x_{k}(k=0,1, \ldots, n)$. Without any loss of generality, we can suppose that:

$$
a \leq x_{0} \leq x_{1} \leq \ldots \leq x_{n} \leq b .
$$


We will assume that points $x_{k}$ are, so called, interpolation nodes, and we will take functions:

$$
\varphi_{k}(x)=x^{k}(k=0,1, \ldots, n) .
$$

Then, interpolation function for function $f(x)$ is algebraic polynomial:

$$
P_{n}(x)=\varphi(x)=a_{0}+a_{1} x+a_{2} x^{2}+\ldots+a_{n} x^{n} .
$$

Next theorem will be given without a proof (see Milovanovic G, 1991).

Theorem 1. Polynomial $P_{n}(x)$ is unique and it can be presented as:

$$
P_{n}(x)=\sum_{k=0}^{n} f\left(x_{k}\right) L_{k}\left(x_{k}\right),
$$

Where:

$$
L_{k}=\frac{\left(x-x_{0}\right) \cdots\left(x-x_{k-1}\right)\left(x-x_{k+1}\right) \cdots\left(x-x_{n}\right)}{\left(x_{k}-x_{0}\right) \cdots\left(x_{k}-x_{k-1}\right)\left(x_{k}-x_{k+1}\right) \cdots\left(x_{k}-x_{n}\right)} .
$$

Polynomial $P_{n}$ from previous theorem is well known as Lagrange interpolation polynomial. Expression $L_{k}$ could be written, also, as:

$$
L_{k}=\frac{\prod_{j=0, j \neq k}^{n}\left(x-x_{j}\right)}{\prod_{j=0, j \neq k}^{n}\left(x_{k}-x_{j}\right)} .
$$

or as:

$$
L_{k}=\frac{\omega(x)}{\left(x-x_{n}\right) \omega \prime\left(x_{k}\right)} \text {, where } \omega(x)=\left(x-x_{0}\right)\left(x-x_{1}\right) \cdots\left(x-x_{n}\right) .
$$

If we approximate the function $f(x)$ with the polynomial $P_{n}(x)$, there is some error. This error could be described with:

$$
R_{n}(f ; x)=f(x)-P_{n}(x) .
$$

The estimation of this error is shown in the next theorem, also given without the proof (Milovanovic G.V, 1991).

Theorem 2. Let $f \in C[a, b]$ and let $x_{i} \in[a, b] i=(0,1, \ldots, n)$. Then there is some arbitrary point $c \in(a, b)$ and the error of interpolation with Lagrange interpolation polynomial is:

$$
R_{n}(f ; x)=f(x)-P_{n}(x)=\frac{f^{(n+1)}(c)}{(n+1) !} \omega(c) .
$$


Lagrange interpolation is very easy for use in practical applications, because linear dependence is easier to be modelled than non-linear dependence models. The applications of Lagrange interpolation are very useful if the goal is prediction. Lagrange interpolation is used to determine the predictive model, according to the considered data set of values. Now, when the appropriate model is obtained, the corresponding value of the dependent variable can be determined for some new values of the independent variable $x$.

Lagrange interpolation (Milovanović G.V., 1991) belongs to polynomial interpolations. This means that an error in interpolation nodes is equal to zero (Milovanović G.V, Kovačević M.A. 1991).

\section{Interpolation formula and the main results}

In this paper, we applied the method of Lagrange interpolation to the given data from the following table, which shows the values of the average salary in Serbia, the value of FONDEX, as well as the number of fund members in the period of 5 years (2015-2019).

Table 3 Data for the Republic of Serbia for the period 2015-2019

\begin{tabular}{llll}
\hline Year & Average salary & FONDEX & $\begin{array}{l}\text { Fund } \\
\text { members }\end{array}$ \\
\hline 2019 & $54.908,25$ & 3064.86 & 201587 \\
\hline 2018 & $49.642,59$ & 2862.92 & 192295 \\
\hline 2017 & $47.887,67$ & 2713.39 & 185445 \\
\hline 2016 & $46.836,75$ & 2592.50 & 183553 \\
\hline 2015 & $44.436,50$ & 2407.45 & 190490 \\
\hline
\end{tabular}

We applied this method to determine the dependence of the number of fund members (column 4) on the average salary (column 2). Then we compare the obtained results with those obtained by mean square approximation method (Randjelovic et al., 2020). The dependences obtained and the predictions calculated are compared.

Based on the data from Table 3, we take the number of fund members (column 4 ) as independent variable $(y)$, and average salary (column 2 ) as the dependent variable $(x)$. We apply Lagrange interpolation formula:

$$
\varphi_{1}(x)=P_{4}(x)=L_{0}(x) f\left(x_{0}\right)+L_{1}(x) f\left(x_{1}\right)+L_{2}(x) f\left(x_{2}\right)+L_{3}(x) f\left(x_{3}\right)+L_{4}(x) f\left(x_{4}\right) .
$$


The initial condition is that the error of interpolation in those nodes is equal to zero, i.e.

$$
\varphi_{1}\left(x_{k}\right)=y\left(x_{k}\right)(k=0, \ldots, n)
$$

where $n=4$. Now we have:

$$
\begin{aligned}
L_{0} \times f\left(x_{0}\right)= & \frac{\left(x-x_{1}\right)\left(x-x_{2}\right)\left(x-x_{3}\right)\left(x-x_{4}\right)}{\left(x_{0}-x_{1}\right)\left(x_{0}-x_{2}\right)\left(x_{0}-x_{3}\right)\left(x_{0}-x_{4}\right)} f\left(x_{0}\right)=\frac{\left(x-x_{1}\right)\left(x-x_{2}\right)\left(x-x_{3}\right)\left(x-x_{4}\right)}{\left(x_{0}-x_{1}\right)\left(x_{0}-x_{2}\right)\left(x_{0}-x_{3}\right)\left(x_{0}-x_{4}\right)} f\left(x_{0}\right) \\
& =421.8115 \times(x-46.836750)(x-47.887670)(x-49.642590)(x-54.908250) \\
L_{1} \times f\left(x_{1}\right)= & \frac{\left(x-x_{0}\right)\left(x-x_{2}\right)\left(x-x_{3}\right)\left(x-x_{4}\right)}{\left(x_{1}-x_{0}\right)\left(x_{1}-x_{2}\right)\left(x_{1}-x_{3}\right)\left(x_{1}-x_{4}\right)} f\left(x_{1}\right)=\frac{\left(x-x_{0}\right)\left(x-x_{2}\right)\left(x-x_{3}\right)\left(x-x_{4}\right)}{\left(x_{1}-x_{0}\right)\left(x_{1}-x_{2}\right)\left(x_{1}-x_{3}\right)\left(x_{1}-x_{4}\right)} f\left(x_{1}\right) \\
& =-3213.06 \times(x-44.436500)(x-47.887670)(x-49.642590)(x-54.908250) \\
L_{2} \times f\left(x_{2}\right)= & \frac{\left(x-x_{0}\right)\left(x-x_{1}\right)\left(x-x_{3}\right)\left(x-x_{4}\right)}{\left(x_{2}-x_{0}\right)\left(x_{2}-x_{1}\right)\left(x_{2}-x_{3}\right)\left(x_{2}-x_{4}\right)} f\left(x_{2}\right)=\frac{\left(x-x_{0}\right)\left(x-x_{1}\right)\left(x-x_{3}\right)\left(x-x_{4}\right)}{\left(x_{2}-x_{0}\right)\left(x_{2}-x_{1}\right)\left(x_{2}-x_{3}\right)\left(x_{2}-x_{4}\right)} f\left(x_{2}\right) \\
& =4150.007 \times(x-44.436500)(x-46.836750)(x-49.642590)(x-54.908250) \\
L_{3} \times f\left(x_{3}\right)= & \frac{\left(x-x_{0}\right)\left(x-x_{1}\right)\left(x-x_{2}\right)\left(x-x_{4}\right)}{\left(x_{3}-x_{0}\right)\left(x_{3}-x_{1}\right)\left(x_{3}-x_{2}\right)\left(x_{3}-x_{4}\right)} f\left(x_{3}\right)=\frac{\left(x-x_{0}\right)\left(x-x_{1}\right)\left(x-x_{2}\right)\left(x-x_{4}\right)}{\left(x_{3}-x_{0}\right)\left(x_{3}-x_{1}\right)\left(x_{3}-x_{2}\right)\left(x_{3}-x_{4}\right)} f\left(x_{3}\right) \\
& =-1424.57 \times(x-44.436500)(x-46.836750)(x-47.887670)(x-54.908250) \\
L_{4} \times f\left(x_{4}\right)= & \frac{\left(x-x_{0}\right)\left(x-x_{1}\right)\left(x-x_{2}\right)\left(x-x_{3}\right)}{\left(x_{4}-x_{0}\right)\left(x_{4}-x_{1}\right)\left(x_{4}-x_{2}\right)\left(x_{4}-x_{3}\right)} f\left(x_{4}\right)=\frac{\left(x-x_{0}\right)\left(x-x_{1}\right)\left(x-x_{2}\right)\left(x-x_{3}\right)}{\left(x_{4}-x_{0}\right)\left(x_{4}-x_{1}\right)\left(x_{4}-x_{2}\right)\left(x_{4}-x_{3}\right)} f\left(x_{4}\right) \\
& =64.515137 \times(x-44.436500)(x-46.836750)(x-47.887670)(x-49.642590) \\
& \text { and Lagrange interpolation function is: } \\
& \varphi_{1}(x)=L_{0}(x) f\left(x_{0}\right)+L_{1}(x) f\left(x_{1}\right)+L_{2}(x) f\left(x_{2}\right)+L_{3}(x) f\left(x_{3}\right)+L_{4}(x) f\left(x_{4}\right) .
\end{aligned}
$$

Now, we will apply the obtained formula, on a set of data, where one half of them is inside the sampling interval for calculation of Lagrange interpolation formula and a half of them is outside this interval. The obtained results are shown in column 2 of the next Table 4. Data.

In the same table, we have another set of results, obtained on the same set of data, but using formula from (Randjelovic et al., 2020), using the method of discrete mean square approximation.

$$
\varphi_{2}(x)=-790.405066+3915.118438 x \text {. }
$$


It is in column 3 of Table 4.

Table 4 Prediction of the number of fund members depending on average salary

\begin{tabular}{ccc}
\hline Supposed average salary & Fund members $\varphi_{1}(x)$ & Fund members $\varphi_{2}(x)$ \\
\hline $50.000,00$ & 193959 & 194966 \\
\hline $51.000,00$ & 198551 & 204753 \\
\hline $52.000,00$ & 202413 & 214541 \\
\hline $53.000,00$ & 204709 & 224329 \\
\hline $54.000,00$ & 204573 & 234117 \\
\hline $55.000,00$ & 201106 & 243904 \\
\hline $56.000,00$ & 193380 & 253692 \\
\hline $57.000,00$ & 180437 & 253692 \\
\hline $58.000,00$ & 161284 & 253692 \\
\hline $59.000,00$ & 134902 & 253692 \\
\hline $60.000,00$ & 100237 & 273268 \\
\hline
\end{tabular}

Graph 2. Comparison of behavior of both models

(blue is obtained using Lagrange interpolation formula and red is obtained using linear regression and discrete mean square quadrat approximation)

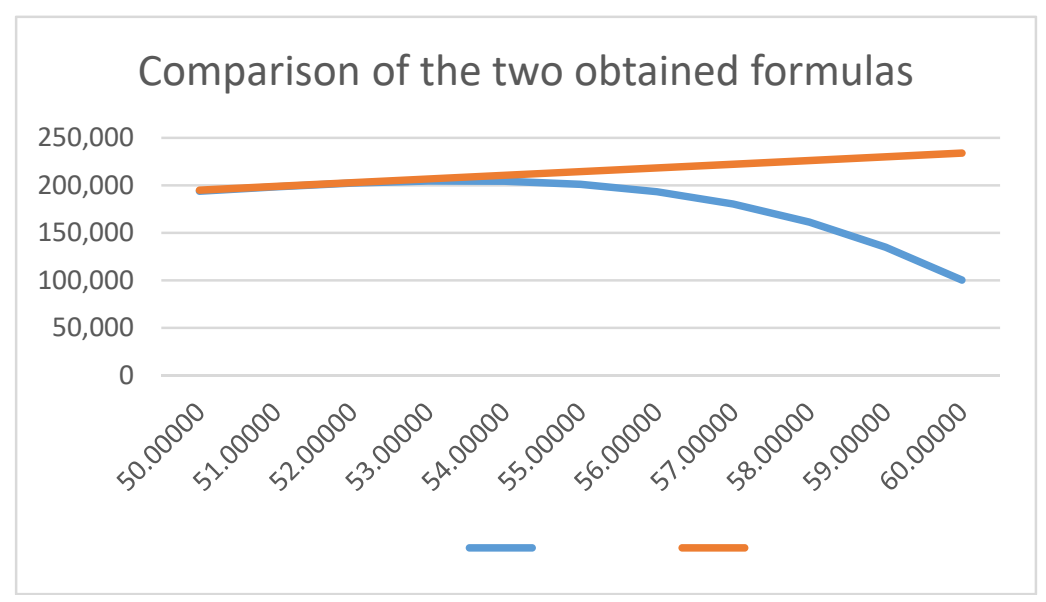


Note (see Graph 2) that we have a very similar behavior of both functions, when the arguments are inside the interval, where nodes for approximation are located (in this case it is interval $[44.436,50 ; 54.908,25]$ ). Even more obvious is that the formula obtained using Lagrange interpolation significantly decreases when the values for the argument are outside the interval with nodes.

\section{Analysis of errors and differences in prediction}

To illustrate the precission and quality of the obtained formulas, we will analyze the errors and differences obtained in the prediction of the number of fund members, using formula with Lagrange interpolation and linear formula applying discrete mean square approximation. We will do it in four cases:

- inside the interpolation nodes (points where data is already known and used for modelling),

- inside our sampling interval, but in the "left" side, where we have more interpolation nodes,

- inside our sampling interval but in the "right" side, where we have less interpolation nodes, and

- outside of the sampling interval.

Table 5 Error analysis in interpolation nodes

\begin{tabular}{cccccc}
\hline $\begin{array}{c}\text { Average } \\
\text { salary }\end{array}$ & $\begin{array}{c}\text { Fund } \\
\text { members }\end{array}$ & $\begin{array}{c}\text { Fund } \\
\text { members } \\
\boldsymbol{\varphi}_{\mathbf{1}}(\boldsymbol{x})\end{array}$ & $\begin{array}{c}\text { Fund } \\
\text { members } \\
\boldsymbol{\varphi}_{\mathbf{2}}(\boldsymbol{x})\end{array}$ & $\begin{array}{c}\text { Maximal } \\
\text { error } \\
\boldsymbol{\varphi}_{\mathbf{1}}(\boldsymbol{x})\end{array}$ & $\begin{array}{c}\text { Maximal error } \\
\boldsymbol{\varphi}_{\mathbf{2}}(\boldsymbol{x})\end{array}$ \\
\hline $44.436,50$ & 190490 & 190490 & 173184 & 0 & $(-) 17306$ \\
\hline $46.836,75$ & 183553 & 183553 & 182581 & 0 & $(-) 972$ \\
\hline $47.887,67$ & 185445 & 185445 & 186696 & 0 & 1250 \\
\hline $49.642,59$ & 192295 & 192295 & 193566 & 0 & 1271 \\
\hline $54.908,25$ & 201587 & 201587 & 214182 & 0 & 12595 \\
\hline
\end{tabular}

The property of each interpolation formula is that error is equal to zero in every interpolation node. So, we can conclude that the mathematical model (formuls), obtained by Lagrange interpolation, is absolutely precise in those nodes. The mathematical model obtained by linear regression method and discrete mean square approximation has some errors in this case, so it is less useful. 
Table 6 Analysis of the obtained results and predictions inside the "left" side of the sampling interval, but outside of interpolation nodes

\begin{tabular}{cccc}
\hline Average salary & $\begin{array}{c}\text { Fund } \\
\text { members } \varphi_{\mathbf{1}}(\boldsymbol{x})\end{array}$ & $\begin{array}{c}\text { Fund } \\
\text { members } \boldsymbol{\varphi}_{\mathbf{2}}(\boldsymbol{x})\end{array}$ & $\begin{array}{c}\text { Difference in prediction } \\
\boldsymbol{\varphi}_{\mathbf{1}}(\boldsymbol{x})-\boldsymbol{\varphi}_{\mathbf{2}}(\boldsymbol{x})\end{array}$ \\
\hline 44.500 .00 & 190049 & 173432 & 16617 \\
\hline $45.000,00$ & 187123 & 175390 & 11733 \\
\hline $45.500,00$ & 185105 & 177348 & 7757 \\
\hline 46.000 .00 & 183916 & 179305 & 4611 \\
\hline $46.500,00$ & 183473 & 181263 & 2210 \\
\hline $47.000,00$ & 183692 & 183220 & -690 \\
\hline $47.500,00$ & 184488 & 185178 & -1364 \\
\hline $48.000,00$ & 185771 & 187135 & -1640 \\
\hline $48.500,00$ & 187453 & 189093 & -1609 \\
\hline $49.000,00$ & 189441 & 191050 & -1366 \\
\hline $49.500,00$ & 191642 & 193008 & \\
\hline
\end{tabular}

Table 7 Analysis of the obtained results and predictions inside the "right" side of the sampling interval, but outside of interpolation nodes

\begin{tabular}{cccc}
\hline Average salary & $\begin{array}{c}\text { Fund } \\
\text { members } \boldsymbol{\varphi}_{\mathbf{1}}(\boldsymbol{x})\end{array}$ & $\begin{array}{c}\text { Fund } \\
\text { members } \boldsymbol{\varphi}_{\mathbf{2}}(\boldsymbol{x})\end{array}$ & $\begin{array}{c}\text { Difference in } \\
\text { prediction } \\
\boldsymbol{\varphi}_{\mathbf{1}}(\boldsymbol{x})-\boldsymbol{\varphi}_{\mathbf{2}}(\boldsymbol{x})\end{array}$ \\
\hline $50.000,00$ & 193959 & 194965 & -1006 \\
\hline $50.500,00$ & 196296 & 196923 & -627 \\
\hline $51.000,00$ & 198551 & 198880 & -329 \\
\hline $51.500,00$ & 200625 & 200838 & -213 \\
\hline $52.000,00$ & 202413 & 202795 & -382 \\
\hline $52.500,00$ & 203811 & 204754 & -943 \\
\hline $53.000,00$ & 204709 & 206711 & -2002 \\
\hline $53.500,00$ & 205000 & 208668 & -6053 \\
\hline $54.000,00$ & 204573 & 210626 & -9271 \\
\hline $54.500,00$ & 203313 & 212584 & -13435 \\
\hline $55.000,00$ & 201106 & 214541 & \\
\hline
\end{tabular}


Lagrange interpolation formula is more precise and has fewer errors, because the degree of used Lagrange polynomial is bigger $(n=4)$ then the formula obtained by mean square approximation, where the polynomial is linear $(n=1)$. So, for the prediction of number of pension fund members, when the average salary is inside this interval, it is better to use a new formula, obtained in the previous part of this paper, based on Lagrange interpolation method.

The similar conclusions like in the previous case. Lagrange interpolation formula is more precise because the degree of used Lagrange polynomial is bigger $(n=4)$ then the formula obtained by mean square approximation, where the polynomial is linear.

Table 8 Analysis of the obtained results and predictions outside of sampling interval

\begin{tabular}{cccc}
\hline Average salary & $\begin{array}{c}\text { Fund } \\
\text { members } \boldsymbol{\varphi}_{\mathbf{1}}(\boldsymbol{x})\end{array}$ & $\begin{array}{c}\text { Fund } \\
\text { members } \boldsymbol{\varphi}_{\mathbf{2}}(\boldsymbol{x})\end{array}$ & $\begin{array}{c}\text { Difference in prediction } \\
\boldsymbol{\varphi}_{\mathbf{1}}(\boldsymbol{x})-\boldsymbol{\varphi}_{\mathbf{2}}(\boldsymbol{x})\end{array}$ \\
\hline $55.000,00$ & 201106 & 214541 & -13435 \\
\hline $55.500,00$ & 197835 & 216499 & -18664 \\
\hline $56.000,00$ & 193380 & 218456 & -25076 \\
\hline $56.500,00$ & 187622 & 220414 & -32792 \\
\hline $57.000,00$ & 180437 & 222372 & -41935 \\
\hline $57.600,00$ & 169755 & 224721 & -54966 \\
\hline $58.000,00$ & 161284 & 226286 & -65002 \\
\hline $58.500,00$ & 149062 & 228244 & -79182 \\
\hline $59.000,00$ & 134902 & 230202 & -95300 \\
\hline $59.500,00$ & 118672 & 232159 & -113487 \\
\hline $60.000,00$ & 100,237 & 234116.7 & $-133,880$ \\
\hline
\end{tabular}

Outside of the interval, linear approximation formula obtained (Randjelovic et al., 2020) has a very similar increasing behavior. The formula obtained by the interpolation decreases very fast, due to a property of polynomials, so there is a very large error. 


\section{Conclusion}

We have three types of conclusions here. The first one is related to the errors in interpolation nodes. The second is about error, approximation and prediction out of the nodes, but still inside our sampling interval. The last one is outside of this interval.

The property of each interpolation formula is that error is equal to zero in every interpolation node. So, we can conclude that the mathematical model (formula) obtained by Lagrange interpolation is absolutely precise in those nodes. The mathematical model obtained by linear regression method and discrete mean square approximation has some errors in this case, so it is less useful. But do we need formulas in those nodes at all? Having in mind that we already started from those values, there will be no need for prediction in those points.

If we analyze the interval of interpolation/approximation, where we calculated and obtained formulas, both mathematical models have some error, but Lagrange interpolation formula is more precise and has fewer errosr, because the degree of the used Lagrange polynomial is bigger $(n=4)$ then the formula obtained by mean square approximation, where the polynomial is linear $(n=1)$. So, for the prediction of the number of pension fund members, when the average salary is inside this interval, it is better to use a new formula, obtained in the previous part of this paper, based on Lagrange interpolation method.

Finally, if we analyze a part of the $x$-axis, outside the interval, we notice that the linear approximation formula, obtained in (Randjelovic et al., 2020) has a very similar increasing behavior. The formula obtained by the interpolation decreases very fast, due to a property of polynomials, so there is a very large error. The conclusion is that the mathematical model using mean square approximation is more useful here.

If we discuss other types and methods of interpolation (for example Newton interpolation formula, Hermite interpolation formula...) in each of them we will have similar conclusions. We will have maximum precision in interpolation nodes (error equal to 0 ) and a significant error outside of them, especially outside of the interval.

If we think about other types and methods of approximation (for example Prony approximation formula, Mean square approximation formula, mini-max approximation formulae...), in each of them we will find similar conclusions like with method used in (Randjelovic B, et al 2020). We will have a small error in the interpolation nodes, but not a significant error outside of them. We are, of course, especially interested for calculations outside the interval.

Further research and analysis should consider determining the structure of the population, which could affect the improvement of the performance of the 
voluntary pension funds in Serbia. The best conclusions obtained from those analyses will lead us to a better prediction of results.

\section{References}

Djekic, M., Nikolic, M., Vesic T. (2019). Challenges and Perspectives of Development of Private Pension Funds in Serbia. Economic Analysis. Vol.52: 69-80.

Kočović, J., Šulejić, P., Rakonjac-Antić, T., (2010). Osiguranje, Ekonomski fakultet, Beograd.

Radojković, I. (2012). Significance and Prospects of Voluntery Pension Funds in Serbia, Tokovi osiguranja, Vol.3:41-47 (in Serbian).

Radojković, I., Gajić B. (2017). Development of Voluntary Pension Funds in Serbia, Tokovi osiguranja, Vol 4: 33-44 (in Serbian).

Benediktsson, H.C., Gerbertssonand T.T., Orszag J.M. (2001). The charge ratio on individual accounts and investment plans in Iceland. Applied Economics, 33(9): 79-87.

Blake, D. (2004). The impact of wealth on consumption and retirement behaviour in the UK. Applied Financial Economics, Vol.14 (5): 55-76.

Chlon, A. (2002). Administrative costs of pension funds in Poland in international perspective, Room Document No.24, Regional Meeting for the Eastern and Central European Countries, Tallinn, Estonia, 7-8 February 2002.

Dellva, W.L., Olson G.T. (1998). The relationship between mutual fund fees and expenses and their effects on performance. The Fin.Review, 33: 85-104.

Ottenand, R., Bams D. (2002). European mutual fund performance. European Financial Management, Vol.8: 75-101.

Statistički godišnji bilten za 2016. (2017). Republički fond za penzijsko i invalidsko osiguranje, Beograd (in Serbian).

Sektor dobrovoljnih penzijskih fondova u Srbiji. (2017). Izveštaj za četvrto tromesečje 2016. Godine, Narodna banka Srbije (in Serbian).

Shamsudin, A.F.M, (2001). Public pension and wealth inequality in Canada. Applied Economics Letters, Vol.8: 315-320.

Kabašinkskas, A., Šutiene, K., Kopaande M. (2017). Valakevičius. (2017). The risk-return profile of Lithuanian private pension funds, Applied Economics, Vol. 30 (1): 16111630.

Kabašinkskas, A., Šutiene, K., Kopaande M. (2017). Discriminatory power and predictions of Defaullts of Structural Credit Risk Models, Journal of Risk Model Validation, 3(4): 39-60.

Bikker, J., Steenbeek, O.W., Torrachu F. (2011). The Impact of Scale, Complexity, and Service Quality on the Administrative costs of Pension Funds: A Cross-Country Comparision, Journal of Risk and Insurance, Vol. 79 (2): 477-514.

Cheng, Ch., Uzelac, F. (2016). A Termination Rule for Pension Guarantee Funds, Journal of Risk and Insurance, Vol.85 (1): 275-300.

Gerke W., Mager, F., Reinschmidt F., Schmieder C. (2008). Empirical Risk Analysis of Pension Insurance: The Case of Germany, Journal of Risk and Insurance, Vol.75 (3): 763-784.

David, O., (2017). Linear Regression, Springer International Publishing.

Milovanović, G.V. (1991). Numerička analiza II, Naučna Knjiga, Beograd. (Serbian). 
Milovanović, G.V., Kovačević, M.A. (1991). Zbirka rě̌enih zadataka iz numeričke analize, Naučna Knjiga, Beograd (Serbian).

Randjelovic B., Radojkovic I., Gajić B. (2020). One Application of Discrete Mean Squere Approximation For Prediction of Voluntary Pension Fund Development, Appl.Math.and Comp.Science,.Vol 5(1): 7-15.

http://www.cekos.rs/indeksi-potro\%C5\%A1a\%C4\%8Dkih-cena-u-2019-godini (accessed March 08, 2020).

http://www.dunavpenzije.com/vesti/stupile-na-snagu-izmene-i-dopune-zakona (accessed May 10, 2017).

https://www.kamatica.com/kursna-lista/nbs/2019-12-31(accessed March 08, 2020).

https://www.kamatica.rs/kursna-lista/nbs/2019-01-03(accessed March 08, 2020).

https://www.nbs.rs/internet/latinica/62/62_2/.

https://www.nbs.rs/internet/latinica/62/62_2/dpf_04_16.pdf p.12

https://www.nbs.rs/internet/latinica/62/62_2/dpf_04_16.pdf p.9

https://www.raiffeisenfuture.rs/fondovi/euro-future/euro-future/prinosi.125.html (accessed March 10, 2020)

https://www.raiffeisenfuture.rs/fondovi/euro-future/euro-future/prinosi.125.html (accessed March 10, 2020)

\section{MODELOVANJE RAZVOJA DOBROVOLJNOG PENZIONOG FONDA KORISTEĆI MATEMATIČKI MODEL APROKSIMACIJE POMOĆU LAGRANŽOVOG INTERPOLACIONOG POLINOMA}

Rezime: Uvođenje privatnih penzionih fondova je osnova reforme penzionog sistema u Srbiji. Privatni penzioni fondovi u Srbiji su bazirani na dobrovoljnosti. Stoga se funkcionisanje privatnih penzionih fondova sprovodi kroz tri uzajamno isprepletana procesa: plaćanje u privatni penzioni fond, investiranje raspoloživih sredstava i programirane isplate - penzije. Stabilnost dobrovoljnih penzijskih fondova i predvidiljvost isplata dovode do kvalitetnog investicijskog portfolija i dugoročno sigurne koristi od investiranja. U ovom radu primenjujemo dobro poznat aproksimaconi metod Lagranžove polinomijalne interpolacije. Koristimo ga da bismo pronašli odgovarajući matematički model za predviđanje broja članova fonda u odnosu na veličinu prosečne plate $u$ Srbiji. Ovo izračunavanje je bazirano na podacima (prosečna plata i broj članova fonda) u poslednjih pet godina, tj. za period 2015-2019. Mi precizno određujemo matematičku formulu, onda poredimo rezultate i predviđanja dobijena pomoću te formule i pomoću formule iz jednog od naših ranijih radova. Dati su i odgovarajući zaključci.

Ključne reči: penzioni sistem, dobrovoljni penzioni fond, matematički model, Lagranžova interpolacija 


\section{Authors' biographies}

Ivan D. Radojković was born in Niš (1972). He works in "DUNAV", a company for the management of a voluntary pension fund, at the position of the Branch manager in Nis. He gained a PhD at the University of Nis, Faculty of Mechanical Engineering. His research interests are: risk management, applied mathematics and models of auto-insurance.

Branislav M. Ranđelović (1970) is an assistant professor at the Department of Mathematics, Faculty of Electronic Engineering, University of Nis. Also, he works as an assistant professor at the Department of Mathematics and Informatics and as the Head of department at Teacher education faculty, University of K. Mitrovica. He published more than 50 scientific papers and expert works, 10 textbooks and several publications. He was a participant/researcher on 6 national scientific projects and 12 International educational projects. His research work is focused on the following areas: numerical mathematics and its applications, graph theory and its applications in various fields. He is the Head of the Institute for Education Quality and Evaluation of the Republic of Serbia.

Ivana D. Ilić was born in Nis (1975). She completed the academic studies at University of Niš and the postgraduate studies at the University of Belgrade, Faculty of Mathematics, where she achieved a PhD degree. She worked at the Department of Mathematics, Faculty of Electronic Engineering, and now she is working as an assistant professor at the Department of Mathematics and Informatics, Faculty of Medicine at University of Niš. She published more than 10 scientific papers. Her fields of expertise are Mathematics, Informatics, Probability and Statistics. 